\title{
REVIEW OF 1969 SASKATOON BIRD OBSERVATIONS
}

\section{by J. B. Gollop, Canadian Wildlife Service, Saskatoon}

This is a summary of the more interesting records from Volume 4 of the Saskatoon Bird Review. The Saskatoon District is a 3,600-square-mile block within approximately a 35-mile radius of Saskatoon. The period covered is from December 1, 1968, through November 30, 1969. Winter is defined as December 1, 1968 - March 15, 1969; spring is March 16 - May 31 ; and fall, June 1 - November 30 . The records received are shown in Table 1 .

Compared to 1968 , there were significant increases in the number of reports for each period but a decrease for the spring. While 32,000 records is a commendable and impressive figure for four years, we find that there are adequate breeding records for fewer than 10 of the 130 species that probably breed in the district. No breeding records are on hand for at least 15 species believed to nest regularly: Pigeon Hawk, Ruby-throated Hummingbird, Hairy Woodpecker, Western Wood Pewee, Swainson's Thrush, Redeyed and Warbling Vireos, Tennessee Warbler, Ovenbird, Rose-breasted Grosbeak, Grasshopper Sparrow, Slatecolored Junco, White-throated Sparrow, McCown's and Chestnut-collared Longspurs.

Contributors: Nine parties contributed about 75 per cent of the records: Mrs. W. R. Early, Mr. and Mrs. G. Galloway, Dr. and Mrs. J. B. Gollop, Mr. and Mrs. J. D. Hogg, Dr. and Mrs. C. S. Houston, Mrs. L. M. Hoyte, S. J.
Shadick, Miss L. P. Strom and Mr. and Mrs. J. A. Wedgwood. Another 15 per cent of the 1969 records were from seven parties submitting $200-500$ records each: Mrs. S. J. Aldous, Dr. and Mrs. C. A. Chamberlain, R. E. Gehlert, Mr. and Mrs. W. S. Richards, J. F. Roy, Mr. and Mrs. L. G. Turner and D. W. Whitfield. However, records are not all of equal value and breeding records deserve special mention. Most of these came from a handful of hard workers: Bob Gehlert, Stuart Golly, Stuart Houston, Jim Slimmon, Fred Waite and Doug Whitfield. The editor wishes to thank Bill Richards, Mrs. T. R. Smith and Cliff Matthews who have assisted significantly in the preparation of the Bird Review and the Canadian Wildlife Service which has again handled the typing. Shirley and Jim Wedgwood and Muriel Galloway have begun the formidable job of compiling the first four years' data.

Breeding: Eighty species were found breeding in 1969. Six species made up more than half of the 608 nests, broods and coveys: Mallard (148), American Coot (124), Pintail (52), Marsh Hawk (25), Great Horned Owl (25) and Long-eared Owl (25). There were more nests and broods than usual of all duck species (except American Widgeon and Canvasback), Marsh Hawks, American Coots, Long-eared Owls, Short-eared Owls (20) and Saw-whet Owls (3). Special mention must be made of 50 Tree Swallow nests found in bird

Table 1. Summary of Saskatoon bird records.

\begin{tabular}{|c|c|c|c|c|c|c|c|}
\hline & \multicolumn{4}{|c|}{ 1968-1969 } & \multirow[t]{2}{*}{1969} & \multirow[t]{2}{*}{1968} & \multirow{2}{*}{$\begin{array}{l}1966 \\
1969\end{array}$} \\
\hline & $\begin{array}{l}\text { Dec. } 1- \\
\text { Mar. } 15\end{array}$ & $\begin{array}{r}\text { Mar. 16- } \\
\text { May } 31\end{array}$ & $\begin{array}{c}\text { Mar. - } \\
\text { Sept.* }\end{array}$ & $\begin{array}{l}\text { June 1- } \\
\text { Nov. 30 }\end{array}$ & & & \\
\hline Records & 1,811 & 4,394 & 608 & 5,024 & 11,837 & 9,571 & 32,822 \\
\hline Cards ... & 578 & 1,505 & 397 & 1,507 & 3,987 & 3,994 & 14,635 \\
\hline Contributors & 53 & 51 & 54 & 53 & 101 & 97 & 210 \\
\hline Species .................... & 44 & 195 & 80 & 210 & 230 & 230 & 252 \\
\hline
\end{tabular}

Breeding records only. 
boxes erected in the spring of 1969 by the Saskatoon Junior Natural History Society. Three species not suspected of breeding in the district were found: a brood of Bufflehead at Pike Lake on July 12, a Say's Phoebe's nest with three young near Dundurn on July 1, and a redpoll's nest with three young (which died) and one egg in Saskatoon on April 30. (The redpoll has been written up by Hans Blokpoel for publication.) The first nests in at least four years were found for seven other species: Belted $\mathrm{K}$ ingfisher (first record), B lack-capped Chickadee, Veery, Orange-crowned Warbler (first), American Redstart, Yellowthroat and Rufous-sided Towhee (first, newlyfledged young).

In 1969 for the first time two brownplumaged Marsh Hawks (male and female, trapped and banded) are known to have reared a brood in the Saskatoon district. There were also at least five cases of brown-plumaged birds observed in full courtship flight.

Spring: The major daytime migrations were reported for crows on April 5 and 6, for hawks and eagles on April $12(50+)$ and $13(190)$, for geese, shorebirds, blackbirds, some Franklin's Gulls and a few swallows on May 4, 9,10 and 11 . The only major wave of night migrants occurred on May 15 and 16; particularly noticeable were Hermit, Swainson's and Gray-cheeked Thrushes, Northern Waterthrushes and some other warblers, Harris's, Whitecrowned, Fox and Lincoln's Sparrows.

Several species were reported more commonly in spring than usual: Roughlegged Hawk, Bald Eagle, Sandhill Crane, Piping Plover, White-rumped Sandpiper, Saw-whet Owl, Redbreasted Nuthatch, the above three thrushes and Northern Waterthrush. Other species appeared to be less common: there were no Rusty Blackbirds reported, and Pine Grosbeaks, Tree and White-crowned Sparrows were fewer in numbers. Lark Buntings were reported only from May 17 to June 8 .

While Snowy Owls were in usual numbers through the winter of 196869 , there were fewer in the spring and fall of 1969. Short-eared Owls were much more common in 1969 than in 1968: 103 birds reported December 1 January 18, none January 19 - April 7, 422 from April 8 -August 31, and 5 from September 1 - November 30. Although there were fewer Bohemian Waxwings than usual during the winter, there were more both in spring and fall. Redpolls were much more common in winter, spring and fall. There were no Pine Siskins reported from February 9 to June 5 but they were noticeably more common from then until October 25.

Fall: Northern Phalaropes; Yellowbellied Sapsuckers, Red-breasted Nuthatches, Brown Creepers, Evening and Pine Grosbeaks, Red- and Whitewinged Crossbills, Harris's, Fox and Swamp Sparrows occurred in larger numbers than usual. The main visible migrations were noted as follows: hawks on October 7, 11, 12 and 13 (192 birds in total), nighthawks on August 19 and 20 ( 56 birds) and crows on September 28 (6,740 birds in $1 \frac{1}{4}$ hours $)$. Night migrants showed up primarily in one major wave, October 5, 6 and 7, which was even more pronounced than the May wave: Robins, Hermit, Swainson's and Gray - cheeked Thrushes, Myrtle and Palm Warblers, Northern Waterthrushes, Yellowthroats, Slatecolored Juncos, Tree, Harris's, Whitecrowned, White-throated, Fox and Swamp Sparrows. On September 13, more than 11,000 crows flew into a roost near Strehlow. Marsh Hawks remained particularly late the previous fall, seven birds being seen on five December dates, including two on the 21st.

Large Numbers: For 23 species, the largest flocks, concentrations or oneday counts (by one party) ever recorded around Saskatoon were reported. (Largest one-day counts are in bold type.) The following counts were associated with two of the recently created reservoirs, Blackstrap and Bradwell: 8 Common Loons on June 21; > 309 Western Grebes on September 20; 32 Pied-billed Grebes on August $30 ; 25$ Great Blue Herons on August $30 ; 37$ Black-crowned Night Herons on September 9; 3,850 \pm Lesser 
Scaup on October 11; >175 Common Goldeneye on November 1; > 75 Bufflehead on October 11; $420 \pm$ Ruddy Ducks on September 20; 115 Whiterumped Sandpipers on May $31 ; 105$ Sanderlings on May 31 ; and > 35 Bonaparte's Gulls on October 11. Other high counts were $>12$ Semipalmated Plover on May 19; 6 Piping Plover on May 5; 53 Black-bellied Plover on May 24; 32 Willets on August 30; 86 Greater Yellowlegs on September 20; 7 Knots on May 24; 173 Marbled Godwits on August 23; $>200$ Barn Swallows on September 7; 3 Mourning Warblers on May 24; 10 Yellowthroats on May 28, and $100 \pm$ Common Grackles on September 6 .

Stragglers and Rarities: Thirty-four species were reported on only one or two days during the 12-month period. There was a single bird on each date unless otherwise noted in parentheses. Blue Goose, April 13 (4) and 20 (2); Black Duck, August 20; White-winged Scoter, June 22 (4) and November 8; Hooded Merganser, September 20 (4); Turkey Vulture, April 13; Goshawk, November 1; Prairie Falcon. October 27; Peregrine Falcon, August 3 and 31; Whooping Crane, October 4 (9); Virginia Rail, June 13; Dunlin, May 19 and 24 (2); Buff-breasted Sandpiper, May 23 (3) and $24(25+)$; Hudsonian
Godwit, April 28 and May 23; Forster's Tern, October 11; Hawk Owl, January 5 and March 8; Boreal Owl, February 10; Red-shafted Flicker, April 6 and June 28; Traill's Flycatcher, June 3 (3) and 6; Olive-sided Flycatcher, May 24 and June 6; Purple Martin, May 24 (4); White-breasted Nuthatch, December 26; Long-billed Marsh Wren, May 24; Short-billed Marsh Wren, May 24; Mockingbird, October 6; Townsend's Solitaire, October 13; Nashville Warbler, May 15 and 16; Blackburnian Warbler, October 13; Chestnut-sided Warbler, September 7; Bay - breasted Warbler, October 6; Mourning Warbler, May 24 and 28; Canada Warbler, August 20 and September 19; Grasshopper Sparrow, May 24; Sharp-tailed Sparrow, July 13 and 14 (4), and McCown's Longspur, May 24 (11).

Miscellaneous: There was a new species for the district: a Varied Thrush in the city on October 8, 10 and 11.

An orange-dyed swan (from Chesapeake Bay) was seen migrating northwest on May 4 and four dyed birds spent several days in May on a slough on the city's outskirts. Two partial albino Myrtle Warblers were reported, one on May 17 and one on October 5.

\section{UNUSUALLY LARGE NUMBERS OF ROSS' GEESE OBSERVED AT LAST MOUNTAIN LAKE}

\section{by F. W. Lahrman, Saskatchewan Museum of Natural History, Regina}

On September 27, 1970, I observed flocks of Ross' Geese departing from the north end of Last Mountain Lake near Watertown during their evening flight to the stubble fields to feed. In past years, I have seen a few individuals or small flocks numbering up to 50 birds. (See Blue Jay 15:165, December, 1961). This evening, however, I estimated the total of birds in flocks that passed by close enough for identification to be well over 1,000 . I counted 300 in one flock, but the usual number per flock was 30 to 50 . Most of the
Ross's were flying in flocks of their own species, but a few were accompanied by White-fronts or Snows, and at times, a few Ross's accompanied flocks of White-fronts.

It is interesting to note that on this date, eight Ross' Geese were also seen at Deep Lake (five miles south of Indian Head) by Lorne Scott. From previous observations, we consider Deep Lake to be a very important breeding and resting area for a great variety of waterfowl, and it is to be hoped that it will remain a protected 